\title{
Screening of Bacillus thuringiensis strains effective against mosquitoes
}

\author{
Rose Gomes Monnerat( ${ }^{(1)}$, Daniel Gerhein Souza Dias ${ }^{(1)}$, Silvania Ferreira da Silva(1), Erica Soares Martins ${ }^{(1)}$, \\ Colin Berry(2), Rosana Falcão ${ }^{(1)}$, Ana Cristina Menezes Mendes Gomes ${ }^{(1)}$, Lilian Botelho Praça ${ }^{(1)}$ \\ and Carlos Marcelo Silveira Soares ${ }^{(3)}$
}

\begin{abstract}
(1)Embrapa Recursos Genéticos e Biotecnologia, Caixa Postal 02372, Brasília, DF, Brazil. E-mail: rose@cenargen.embrapa.br (2)Cardiff School of Biosciences, Cardiff University, P.O. Box 911, Museum Avenue, Cardiff, CF10 3US, Wales, UK. E-mail: berry@cf.ac.uk(3)Bthek Biotecnologia Ltda, SAAN Qd. 3 Lote 240, Brasília, DF, Brazil. E-mail: marcelo@bthek.com.br
\end{abstract}

\begin{abstract}
The objective of this work was to evaluate 210 Bacillus thuringiensis strains against Aedes aegypti and Culex quinquefasciatus larvae to select the most effective. These strains were isolated from different regions of Brazil and are stored in a Bacillus spp. collection at Embrapa Recursos Genéticos e Biotecnologia, Brasília, Brazil. The selected strains were characterized by morphological (microscopy), biochemical (SDS-PAGE $10 \%$ ) and molecular (PCR) methods. Six B. thuringiensis strains were identified as mosquito-toxic after the selective bioassays. None of the strains produced the expected PCR products for detection of cry 4 , cry 11 and cytlA genes. These results indicate that the activity of mosquitocidal Brazilian strains are not related with Cry4, Cry11 or Cyt proteins, so they could be used as an alternative bioinsecticide against mosquitoes.
\end{abstract}

Index terms: Culex quinquefasciatus, Aedes aegypti, bioinsecticide.

\section{Prospecção de estirpes de Bacillus thuringiensis efetivas contra mosquitos}

\begin{abstract}
Resumo - Neste trabalho foram realizados testes de patogenicidade com 210 estirpes de Bacillus thuringiensis contra larvas de Aedes aegypti e Culex quinquefasciatus, a fim de se determinar as mais eficazes. Estas estirpes foram isoladas de diversas regiões do Brasil e estão armazenadas na coleção de Bacillus spp. da Embrapa Recursos Genéticos e Biotecnologia. As estirpes selecionadas foram caracterizadas por métodos morfológicos (microscopia), bioquímicos (SDS-PAGE 10\%) e moleculares (Reação em Cadeia da Polimerase). Foram selecionadas seis estirpes entomopatogênicas de Bacillus thuringiensis. Nenhuma das estirpes de Bacillus thuringiensis apresentou produtos de PCR esperados para a detecção dos genes cry4, cryll e cytlA. A patogenicidade das estirpes não está associada à presença das toxinas Cry4, Cry11 ou Cyt, assim, essas estirpes poderão ser utilizadas para a formatação de um bioinseticida alternativo contra mosquitos.
\end{abstract}

Termos para indexação: Culex quinquefasciatus, Aedes aegypti, bioinseticida.

\section{Introduction}

In Brazil, some mosquito species of the family Culicidae and Blackflies (Simulidae) are considerable vectors of human and animal diseases. For example, Aedes aegypti was responsible for more than 750,000 occurences of dengue fever in Brazil during the summer of 2001/2002 (Vilarinhos, 2002).

Among the strategies used to control the endemic vectors, the World Health Organization recommends the use of bioinsecticides based on Bacillus thuringiensis (WORLD HEALTH ORGANIZATION, 1985). The advantages in using this bacterium are its specificity, the absence of pollution and of toxicity to mammals, other vertebrates or against plants (Whiteley \& Schnepf, 1986). This bacterium exhibits high genetic variability, producing more than 40 different classes of toxins against insects of the orders Diptera, Lepidoptera and Coleoptera (Feitelson et al., 1992). Researchers in several parts of the world are looking for new strains of $B$. thuringiensis that are able to produce new toxins.

Products based on this bacterium have been commercialized around the world for more than 50 years. At present, in Brazil, there has been no commercial production of bioinsecticides based on this bacterium, so that the products currently used are expensive, in some cases preventing its utilization.

Embrapa Recursos Genéticos e Biotecnologia maintains a culture collection of entomopathogenic Bacillus spp. in which around 1,400 B. thuringiensis (Bt) strains are stored (Monnerat et al., 2001). 
The aim of this work was to characterize the B. thuringiensis strains of the Embrapa culture collection and to identify strains that could be used to control A. aegypti and Culex quinquefasciatus.

\section{Material and Methods}

Two hundred and ten $B$. thuringiensis strains stored in the collection of Entomopathogenic Bacillus spp. of Embrapa Recursos Genéticos e Biotecnologia were used. These strains were originally isolated from water and soil samples collected from different Brazilian regions (Monnerat et al., 2001).

Two kinds of bioassays were performed to determine the biological activity of the strains, a selective bioassay to determine the pathogenic activity of the strain and a quantified bioassay to determine the virulence of the strains through determination of $50 \%$ lethal concentration $\left(\mathrm{LC}_{50}\right)$.

All strains were grown in NYSM medium (Yousten, 1984) for 48 hours at $28^{\circ} \mathrm{C}$ and $200 \mathrm{rpm}$ and tested against $3^{\text {rd }}$ instar larvae of $C$. quinquefasciatus and A. aegypti. One $\mathrm{mL}$ of total culture of each strain was added to $200 \mathrm{~mL}$ cups in triplicate with $100 \mathrm{~mL}$ of distilled water and 25 larvae of $C$. quinquefasciatus or A. aegypti. One cup without bacteria was used as the control. Forty-eight hours later, the number of dead larvae was evaluated. The strains that killed more than $50 \%$ of the larvae were considered pathogenic (Silva-Werneck \& Monnerat, 2001).

In order to determine the $\mathrm{LC}_{50}$, several dilutions of the lyophilised final culture prepared as described above were used. One $\mathrm{mL}$ of these dilutions was added into $200 \mathrm{~mL}$ cups in triplicate, as for the procedure used in selective bioassays. Forty-eight hours later the numbers of dead larvae were recorded and the $\mathrm{LC}_{50}$ (lethal concentration necessary to kill $50 \%$ of larvae) was calculated by Probit analysis (Finney, 1971). Bacillus thuringiensis israelensis (IPS-82, from the Pasteur Institute) was used as standard.

For the analysis of protein profile, spore-crystal mixtures of the $B$. thuringiensis strains and the standard strain HD-1 were prepared by a rapid washing procedure (Lecadet et al., 1992). Samples (1.5 mL) of sporulated cultures were centrifuged at $11,750 \mathrm{~g}$ in a microcentrifuge for 20 minutes and washed once in $1.5 \mathrm{~mL}$ of $0.5 \mathrm{M}$ $\mathrm{NaCl}$ and twice in cold sterilized water containing $1.0 \mathrm{mM}$ of the protease inhibitor, phenylmethylsulfonyl fluoride (PMSF). The pellets were resuspended in $250 \mu \mathrm{L}$ of
1.0 $\mathrm{mM}$ PMSF and kept frozen at $-20^{\circ} \mathrm{C}$. The protein composition of the spore-crystal mixtures was determined by SDS-PAGE (sodium dodecyl sulfate-polyacrylamide gel electrophoresis) with $10 \%$ acrylamide. Fifteen $\mu \mathrm{L}$ of the prepared sample was separated by electrophoresis at $125 \mathrm{~V}$ for two hours. Bacillus thuringiensis israelensis (IPS-82, from the Pasteur Institute) was used as standard.

The method used for analysis of the presence of $B$. thuringiensis toxin genes by polymerase chain reaction (PCR) was described by Bravo et al. (1998). B. thuringiensis strains were grown on NYSM agar for 16 hours, at $30^{\circ} \mathrm{C}$. Cells were resuspended in MilliQ water and frozen at $-80^{\circ} \mathrm{C}$ for one hour and then transferred to boiling water for 10 minutes to lyse the cells. Primers designed for detecting genes cry4, cry 11 and $c y t 1 A$ were used. Fifteen $\mu \mathrm{L}$ of supernatant obtained from cell lysates of the $B$. thuringiensis strains were transferred to a $200-\mu \mathrm{L}$ reaction tube containing $0.5 \mu \mathrm{M}$ of each primer, $0.2 \mathrm{mM}$ of each dNTP, $1 \mathrm{x}$ Taq polymerase buffer, $1.5 \mathrm{mM} \mathrm{MgCl} 2$ and $2.5 \mathrm{U}$ of $\mathrm{Taq}$ DNA polymerase in a final volume of $50 \mu \mathrm{L}$. PCR amplification was performed with a Programmable Thermal Controller. The conditions used for the PCRs were those described by Carozzi et al. (1991) (cry4) and Bravo et al. (1998) (cryll and cyt). After amplification, a 15- $\mu \mathrm{L}$ sample of the product from each PCR reaction was subjected to electrophoresis in a $2 \%$ $(\mathrm{w} / \mathrm{v})$ agarose gel in Tris-borate buffer at $100 \mathrm{~V}$ for one hour and stained with ethidium bromide.

Crystalline inclusions of each strain were purified from the sporulated culture by centrifugation in discontinuous sucrose gradient (Thomas \& Ellar, 1983). Each strain was grown on five nutrient agar plates, at $30^{\circ} \mathrm{C}$, for 48 hours. The culture was collected in $20 \mathrm{~mL}$ milliQ water and centrifuged at 12,800 $g$ for 10 minutes at $15^{\circ} \mathrm{C}$. The pellet was washed three times in $0.1 \mathrm{mM}$ of the protease inhibitor PMSF, $0.01 \%$ Triton X100. The final pellet was resuspended in $2-5 \mathrm{~mL}$ of the following

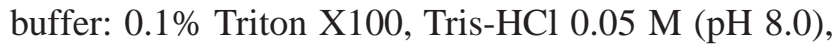
$0.01 \mathrm{M} \mathrm{NaCl}$, and sonicated three times for one minute. The spore-crystal mixture was layered on top of a $28 \mathrm{~mL}$ discontinuous sucrose gradient, comprising $7 \mathrm{~mL}$ each of $67 \%, 72 \%, 79 \%$ and $84 \%(\mathrm{w} / \mathrm{v})$ sucrose in $0.01 \%$ Triton X100, Tris-HCl 0.05 M (pH 8.0), $0.01 \mathrm{M} \mathrm{NaCl}$. Centrifugation was carried out in an ultracentrifuge, in an AH627 rotor at $47,800 \mathrm{~g}$ for $30 \mathrm{~min}$ at $15^{\circ} \mathrm{C}$. The bands were collected from the interfaces, washed once in the same volume of $0.01 \%$ Triton X100 by 
centrifugation at $12,800 \mathrm{~g}$ for 10 minutes, at $15^{\circ} \mathrm{C}$, and twice in $1 \mathrm{~mL}$ of this solution. The final pellet was resuspended in $500 \mu \mathrm{L}$ of $0.1 \mu \mathrm{M}$ PMSF, the crystals observed by phase-contrast microscopy and stored at $-20^{\circ} \mathrm{C}$.

The crystalline inclusions of strains were lyophilized and deposited under a metallic support. The samples were covered with gold for 180 seconds, using sputter EMITECH model K550 and observed in a scanning microscope.

\section{Results and Discussion}

Six B. thuringiensis strains were identified as mosquito toxic in the selective bioassays. Four of them showed toxicity against $A$. aegypti and two against both A. aegypti and C. quinquefasciatus (Table 1).

Even though strains were pathogenic, none of them showed lower $\mathrm{LC}_{50}$ than $B$. thuringiensis israelensis against $A$. aegypti. These Brazilian pathogenic strains to A. aegypti presented similar $\mathrm{LC}_{50}$, with $\mathrm{S} 479$ being the most effective among them (Table 1). Between the pathogenic strains to $C$. quinquefasciatus, S550 was as toxic as B. thuringiensis israelensis, while S447 showed a lower efficiency (Table 1).

All strains presented different protein profiles (Figure 1). However, in all cases there is a major protein around $130 \mathrm{kDa}$, a size similar to that of the Cry4 proteins,

Table 1. $\mathrm{LC}_{50}(\mu \mathrm{g} / \mathrm{mL})$ of the most toxic Bacillus thuringiensis strains identified after selective bioassays against Aedes aegypti and Culex quinquefasciatus.

\begin{tabular}{lrc}
\hline Strains & LC $_{50}$ & Fiducial limits \\
\hline & \multicolumn{3}{c}{ Aedes aegypti } \\
S479 & 6.8 & $2.73-29.6$ \\
S1255 & 9.8 & $4.24-11.5$ \\
S550 & 15 & $4.31-96.1$ \\
S447 & 20 & $4.08-84.2$ \\
S285 & 24 & $6.61-181$ \\
S685 & 42 & $9.72-503$ \\
IPS82-(Bti) & 1.1 & $0.82-1.43$ \\
\hline & & Culex quinquefasciatus \\
S550 & 0.073 & $0.048-0.11$ \\
S447 & 0.089 & $0.069-0.12$ \\
IPS82-(Bti) & 0.034 & $0.020-0.065$ \\
\hline
\end{tabular}

encoded by B. thuringiensis israelensis. On the other hand, none of the Brazilian strains produced the expected PCR products for cry 4 genes whereas the control strain Bti IPS82 produced the 797 bp amplicon. Strains S447, S479, S685 and S1255 also produced a protein around $70 \mathrm{kDa}$, a similar size to the Cry11 protein (Figure 1), but again none of the Brazilian strains yielded the $305 \mathrm{bp}$ PCR amplicon that was produced by Bti using the cry 11 specific primers. The same happened when Cyt proteins were analyzed, the strains S447 and S479 exhibited a $30 \mathrm{kDa}$ protein (Figure 1) but the expected PCR product for cyt gene (525 bp) was not amplified. These results indicated that the activity of mosquitocidal Brazilian strains is not related with Cry4, Cry11 or Cyt proteins.

Morphological analysis by scanning microscopy showed that all strains produce round crystals. Strains S447, S479, S550 and 1255 exhibited round crystals with a size similar to Bti crystals (Figure 2). All strains except S1255 showed also a round crystal smaller and different from Bti crystals. It is likely that mosquitocidal activity of these strains is linked to the presence of round crystals.

Further studies are needed to characterize the proteins detected in this work, however, as the toxins produced by all strains appear to be distinct from the toxins of Bti, these strains could be used as an alternative in programs of mosquito control.

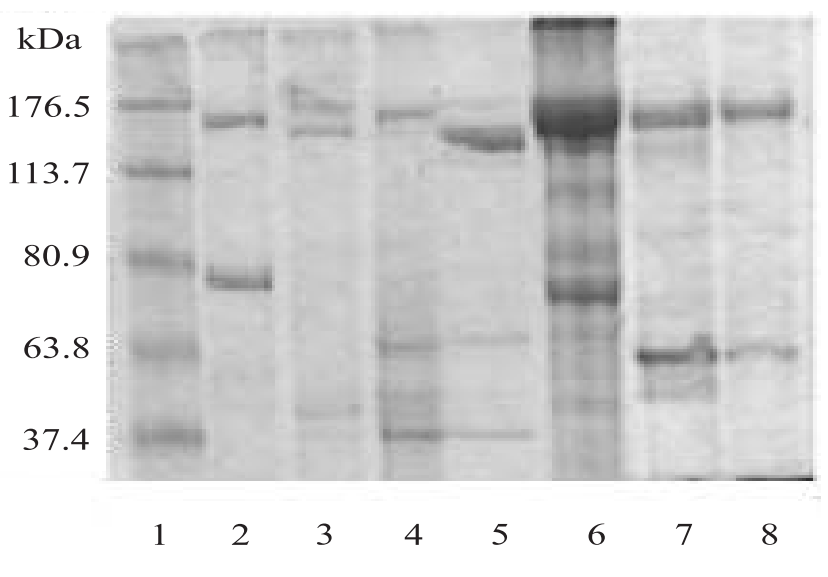

Figure 1. SDS-PAGE of spore-crystal from Bacillus thuringiensis strains. 1: Molecular marker Gibco BRL; 2: Bti; 3: S285; 4: S447; 5: S479; 6: S550; 7: S685; 8: S1255. 

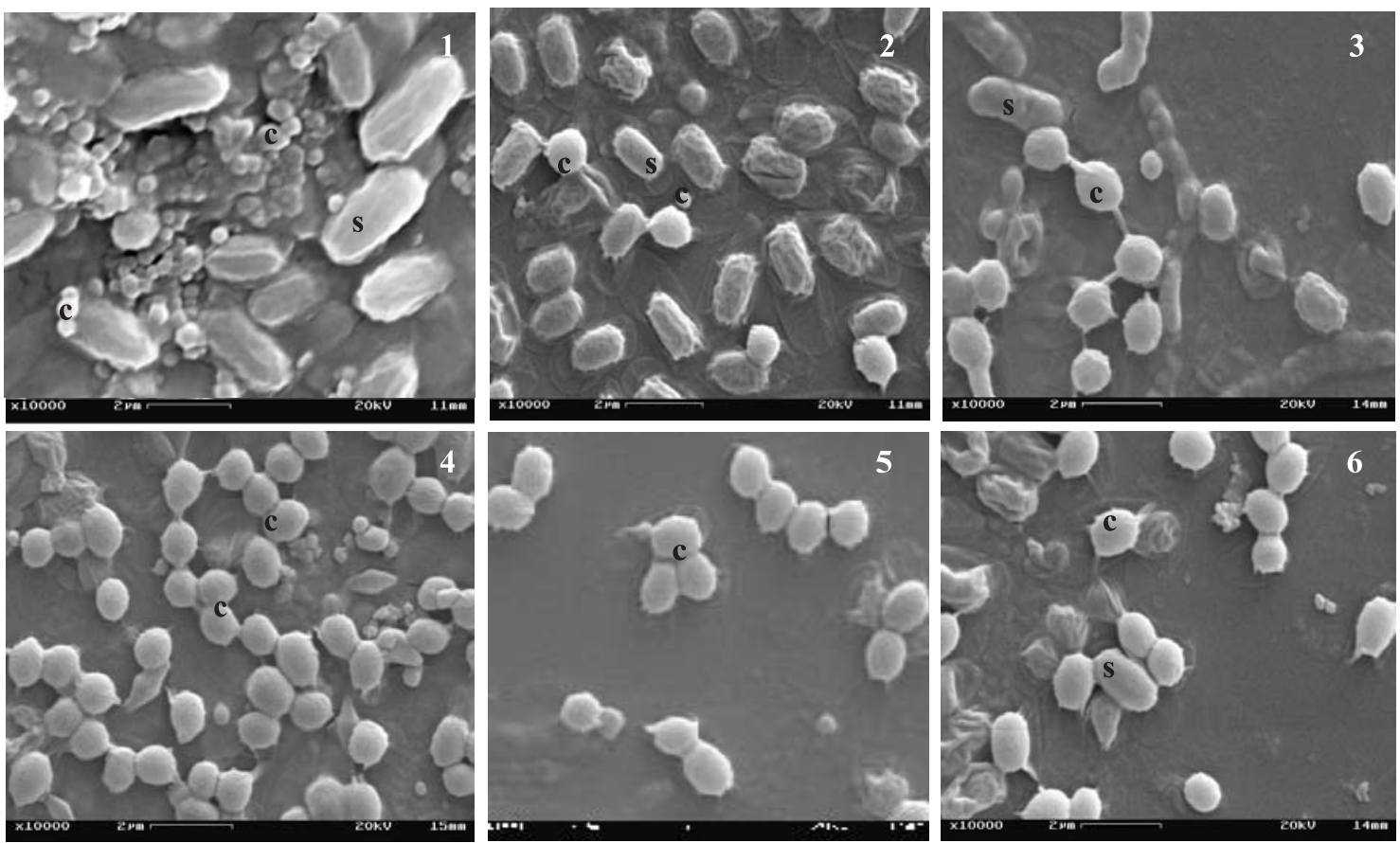

Figure 2. Scanning electron microscopy of spore (s) and crystals (c) of strains S285 (1); S447 (2); S479 (3); S550 (4); S1255 (5); and Bti (6).

\section{Conclusion}

Among 210 Bacillus thuringiensis strains of the Collection of Entomopathogenic Bacillus spp. of Embrapa Recursos Genéticos e Biotecnologia, six are toxic to Aedes aegypti and Culex quinquefasciatus larvae.

\section{References}

BRAVO, A.; SARABIA, S.; LOPEZ, L.; ONTIVEROS, H.; ABARCA, C.; ORTIZ, A.; ORTIZ, M.; LINA, L.; VILLA-LOBOS, F.J.; GUADALUPE, P.; NUNEZ-VALDEZ, M.E.; SOBERÓN, M.; QUINTERO, R. Characterization of cry genes in Mexican Bacillus thuringiensis strain collection. Applied and Environmental Microbiology, v.64, p.4965-4972, 1998.

CAROZZI, N.B.; KRAMER, V.C.; WARREN, G.W.; EVOLA, S.; KOZIEL, M.G. Prediction of insecticidal activity of Bacillus thuringiensis strains by polymerase chain reaction product profiles. Applied and Environmental Microbiology, v.57, p.3057-3061, 1991.

FEITELSON, J.S.; PAYNE, J.; KIM, L. Bacillus thuringiensis insects and beyond. Biotechnology, v.10, p.271-275, 1992.

FINNEY, D.J. Probit analysis. Cambridge, England: Cambridge University Press, 1971. 31p.

LECADET, M.M.; CHAUFAUX, J.; RIBIER, J.E.; LERECLUS, D. Construction of novel Bacillus thuringiensis strains with differ- ent insecticidal activities by transduction and transformation. Applied and Environmental Microbiology, v.58, p.840-849, 1992.

MONNERAT, R.G.; SILVA, S.F.; SILVA-WERNECK, J.O. Catálogo do banco de germoplasma de bactérias do gênero $B a$ cillus. Brasília: Embrapa-Cenargen, 2001. 65p. (Documentos, 60).

SILVA-WERNECK, J.O.; MONNERAT, R. Metodologias para caracterização de isolados de Bacillus thuringiensis. Brasília: Embrapa-Cenargen, 2001. 5p. (Circular Técnica, 10).

THOMAS, W.E.; ELLAR, D.J. Bacillus thuringiensis var. israelensis crystal-endotoxin: effects on insect and mammalian cells in vitro and in vivo. Journal of Cell Science, v.60, p.181-197, 1983.

VILARINHOS, P.T.R. Dengue transmission and Aedes aegypti control in Brazil. In: INTERNATIONAL COLLOQUIUM ON INVERTEBRATE PATHOLOGY AND MICROBIAL CONTROL, 8.; INTERNATIONAL CONFERENCE ON BACILLUS THURINGIENSIS, 6.; ANNUAL MEETING OF THE SOCIETY FOR INVERTEBRATE PATHOLOGY, 35. 2002, Foz do Iguassu. Proceedings. Londrina: Embrapa Soja; UEL: SIP, 2002. p.55-57.

WHITELEY, H.R.; SCHNEPF, H.E. The molecular biology of parasporal crystal body formation in Bacillus thuringiensis. Annual Review of Microbiology, v.40, p.549-576, 1986.

WORLD HEALTH ORGANIZATION (WHO). Informal consultation on the development of Bacillus sphaericus as a microbial larvicide. Special Programme for Research and Training in tropical Diseases, TDR/BCV/SPHAERICUS/85.3. 1985.

YOUSTEN, A.A. Bacillus sphaericus: Microbiological factors related to its potential as a mosquito larvicide. Advances in Biotechnology Processes, v.3, p.315-343, 1984.

Received on February 16, 2004 and accepted on September 28, 2004 